\title{
PENGARUH MINUMAN BEROKSIGEN TERHADAP SISTEM IMUN, KADAR MALONALDEHIDA DAN PERFORMA RESPONDEN MAHASISWA OLAHRAGAWAN
}

\author{
[Effect of Oxygenated Water on Immune System, Malonaldehyde Content \\ and Student-Athlete Performance]
}

Cesar Welya Refdi, Fransiska Rungkat Zakaria* dan Puspo Edi Giriwono

Departemen IImu dan Teknologi Pangan, Fakultas Teknologi Pertanian, Institut Pertanian Bogor, Bogor

Diterima 23 Agustus 2013 / Disetujui 01 Juli 2014

\begin{abstract}
Exercise requires more oxygen input and cannot be fully obtained through breathing. The body has a homeostatic system, when more ATP is needed, the more oxygen is required by the body. Limited supply of oxygen such as those happens in athlete's body automatically switches the respiration from aerobic into anaerobic. This situation results in building up of lactic acid which in turn lowers the energy for cellular metabolism as well asenergy for exercise. The purpose of this study was to assess the effects of short-term and long-term drinking of oxygenated water on lactic acid and energy expenditure (EE) in exercise performance; Cluster of Differentiation-4 (CD4), CD8, CD56, Interleukin-6 (IL-6) contents; and level of malonaldehyde. During short-term intervention, 12 male student volunteers drank oxygenated (50, 80 and 130 ppm) water and normal mineral water, 15 minutes before treadmill and after treadmill $(10 \mathrm{Kmh})$. The lactic acid concentration was measured before and after treadmill, and 5 minutes after the reconsumption of the oxygenated water. During long-term intervention, 17 male student volunteers drank oxygenated (100 ppm) water twice a day for 21 days. The blood plasma and lymphocyte sampled before and after intervention were analyzed for the same parameters. The results showed that oxygenated water had no effect on lactic acid accumulations and EE. Similarlyt he long-term study showed that oxygenated water did not affect CD4 and CD8, had no harmful effect on IL-6 and malonaldehyde, yet it significantly increased the CD56 content.
\end{abstract}

Keywords: exercise performance, immune system, malonaldehyde, oxygenated water

\begin{abstract}
ABSTRAK
Pada saat berolahraga, tubuh membutuhkan oksigen yang lebih banyak dan tidak dapat diperoleh sepenuhnya dari pernafasan. Tubuh memiliki sistem homeostatis; semakin banyak jumlah ATP yang dibutuhkan, maka semakin banyak oksigen yang dibutuhkan oleh tubuh. Keterbatasan oksigen pada tubuh olahragawan dapat mengakibatkan respirasi aerob beralih ke respirasi anaerob secara otomatis. Keadaan ini mengakibatkan penumpukan asam laktat, menurunkan energi untuk berolahraga, dan energi untuk metabolisme selular. Penelitian ini bertujuan untuk mengkaji pengaruh konsumsi minuman beroksigen dalam jangka pendek dan jangka panjang terhadap kadar asam laktat dan energy expenditure pada saat berolah raga; kadar protein Cluster of Differentiation-4 (CD4), CD8, CD56, dan Interleukin-6 (IL-6); serta kadar malonaldehida. Intervensi jangka pendek diikuti oleh 12 orang responden (mahasiswa, laki-laki) setiap responden mengonsumsi minuman beroksigen berbagai konsentrasi (50, 80 dan 130 ppm) dan AMDK (Air Minum Dalam Kemasan) pada hari yang berbeda, 15 menit sebelum dan setelah treadmill $(10 \mathrm{~km} / \mathrm{jam})$. Pengukuran kadar asam laktat dilakukan sebelum treadmill, setelah treadmill dan 5 menit setelah mengonsumsi minuman beroksigen setelah treadmill. Intervensi dalam jangka panjang diikuti 17 orang responden (mahasiswa, laki-laki) mengonsumsi minuman beroksigen (100 ppm) dua kali sehari selama 21 hari. Plasma darah dan limfosit yang diambil sebelum dan setelah intervensi dianalisa untuk parameter yang sama. Hasil menunjukkan bahwa minuman beroksigen tidak mempengaruhi kadar asam laktat dan EE dalam intervensi jangka pendek. Intervensi jangka panjang selama 21 hari menunjukkan bahwa minuman beroksigen tidak mempengaruhi kadar CD4 dan CD8, namun dapat dinyatakan aman berdasarkan kadar IL-6 dan malonaldehida, serta dapat meningkatkan kadar CD56 secara signifikan.
\end{abstract}

Kata kunci: sistem imun, malonaldehida, minuman beroksigen, performa berolahraga

\section{PENDAHULUAN}

Oksigen merupakan zat yang essensial bagi hidup manusia, tersedia di udara dan dapat dinikmati secara bebas. Namun, beberapa kalangan sering mengalami keterbatasan dalam memperoleh oksigen yang cukup. Olahragawan dalam akitivitas olahraganya membutuhkan oksigen yang lebih banyak dan tidak dapat sepenuhnya diperoleh dari hirupan udara

*Penulis Korespondensi:

E-mail: fzakaria@ipb.ac.id (pernafasan). Tubuh memiliki sistem homeostatis; semakin banyak jumlah ATP yang dibutuhkan, maka semakin banyak oksigen yang diperlukan oleh tubuh. Konsumsi oksigen saat istirahat pada orang dewasa adalah sekitar $250 \mathrm{~mL} /$ menit dan meningkat hingga lebih dari $4000 \mathrm{~mL} /$ menit saat olah raga berat (Ward et al. 2007).

Keterbatasan oksigen dalam tubuh olahragawan dapat mengakibatkan respirasi aerob beralih ke respirasi anaerob secara otomatis. Siklus Krebs dan rantai transport elektron tidak berlangsung, sebaliknya terjadi fermentasi asam piruvat yang menghasilkan asam laktat (Campbell et al. 2000). Total energi 
yang dihasilkan pada respirasi anaerob sangat kecil yaitu hanya 2 ATP dari proses glikolisis, dibandingkan dengan 38 ATP dari respirasi aerob. Energi ini tidak cukup untuk menjalankan fungsi-fungsi tubuh dalam jangka waktu lama. Selain itu, penumpukan asam laktat di otot menyebabkan kelelahan dan lebih lanjut menurunkan performa dan prestasi olahragawan. Performa olahraga terkait pada prestasi olahraga yang mencakup penampilan fisik seperti stamina dan kekuatan fisik (Santosa dan Dikdik, 2012). Performa olahraga dapat diukur berdasarkan tingkat kelelahan (peningkatan asam laktat) dan energi yang dikeluarkan (EE).

Kebutuhan oksigen ini mendorong para ilmuwan dan industri untuk menciptakan alternatif suplai oksigen di dalam tubuh melalui air minum. Oksigen yang masuk melalui saluran pencernaan dapat berdifusi dalam darah dan diharapkan dapat meningkatkan ketersediaan oksigen dalam tubuh serta memberikan efek menguntungkan bagi kesehatan konsumen. Namun, Piantadosi (2006) menyebutkan bahwa penyerapan air beroksigen oleh usus secara signifikan tidak memberikan pengaruh pada performa seseorang yang berolahraga. Kelemahan dari penelitian Piantadosi hanya mengukur saturasi oksigen yang peningkatannya tidak dapat dilihat pada orang yang sehat, terutama pada orang sehat yang gemar berolahraga. Adanya keraguan penyerapan oksigen oleh usus telah dijawab oleh penelitian Nestle et al. (2004) yang dibuktikan menggunakan metode MRI. Penelitian Nestle et al. membuktikan bahwa meminum air beroksigen dengan kandungan $\mathrm{CO}_{2}$ yang rendah, dapat meningkatkan jumlah oksigen pada lumen oral cavity dan usus.

Oksigen yang cukup juga berperan dalam memperoleh metabolisme sel yang normal, termasuk pada sel-sel imun. Di dalam sistem imun terdapat berbagai macam sel yang secara terstruktur menjaga pertahanan tubuh. CD4 yang merupakan protein penanda pada sel $T$ helper (Th) dan berfungsi untuk aktivasi makrofag dan produksi antibodi, CD8 merupakan protein penanda pada sel $T$ cytotoxyc (Tc) yang berfungsi untuk membunuh sel-sel termutasi (sel kanker dan tumor) dan sel yang terinfeksi oleh virus, CD56 merupakan protein penanda sel Natural Killer (NK) yang berfungsi membunuh sel tumor dan sel terinfeksi virus secara spesifik atau non spesifik (Orange dan Ballas, 2006). IL-6 mengalami peningkatan pada saat terjadi kontraksi otot selama berolahraga sekaligus sebagai indikator terjadinya inflamasi (Whitham et al. 2012).

Selain itu, efek negatif yang dikhawatirkan adalah pembentukan Reactive Oxygen Species (ROS). Radikal bebas dan senyawa oksigen reaktif yang diproduksi dalam jumlah yang normal, penting untuk fungsi biologis, seperti sel darah putih yang menghasilkan $\mathrm{H}_{2} \mathrm{O}_{2}$ untuk membunuh beberapa jenis bakteri dan jamur serta pengaturan pertumbuhan sel, namun tidak menyerang sasaran spesifik, sehingga memungkinkan menyerang asam lemak tidak jenuh ganda dari membran sel, organel sel, atau DNA, selanjutnya dapat menyebabkan kerusakan struktur dan fungsi sel (Heryani et al. 2011). Perubahan kadar malonal dehida (MDA) responden diamati untuk menjadi indikator keamanan konsumsi minuman beroksigen pada ROS.

Penelitian ini bertujuan untuk mengetahui pengaruh konsumsi minuman beroksigen terhadap kadar asam laktat; EE; kadar protein CD4, CD8, CD56 dan IL-6. Selain itu, penelitian juga ditujukan untuk melihat keamanan konsumsi minuman beroksigen berdasarkan kadar malonaldehida. Penelitian ini diharapkan dapat menjadi temuan baru bahwa konsumsi minuman beroksigen dapat meningkatkan performa olahraga dan sistem imun serta aman untuk dikonsumsi secara terusmenerus.

\section{BAHAN DAN METODE}

\section{Bahan}

Bahan utama yang digunakan adalah sampel minuman beroksigen dengan konsentrasi oksigen 50, 80 dan 130 ppm dan Air Minum Dalam Kemasan (AMDK) sebagai kontrol untuk jangka pendek, serta sampel minuman beroksigen 100 ppm untuk jangka panjang. Bahan pada isolasi limfosit adalah EDTA $1 \%$, cairan histopaque (Sigma-1077) (fycoll-hypaque), PBS (Sigma-P3563) dan trifan blue. Bahan kimia yang digunakan untuk analisa dengan ELISA adalah Phosphat Buffer Saline (PBS) (Sigma-P3563), skim milk 5\%, antibodi Monoclonal antiCD4 human produced in rabbit (sc-70665 Santa Cruz), antibodi Monoclonal anti-CD8 human produced in mouse (GTX83296 GeneTex), antibodi Monoclonal anti-CD56 human produced in mouse (GTX76336 Gene Tex), antibodi Monoclonal anti-IL-6 human produced in mouse (sc-28343 Santa Cruz), antibodi sekunder anti-IgG antimouse (Horse Radish Peroxidase) (GTX26789), antibodi sekunder [anti-IgG antirabbit (Horse Radish Peroxidase) (SC-2030)] stop solution $\left(\mathrm{H}_{2} \mathrm{SO}_{4} 1 \mathrm{M}\right)$, substrat 3,3',5,5'-Tetramethylbenzidine (TMB) (Sigma T4444). Reagen analisis malonaldehida adalah thrichloroacetic (TCA), thiobarbituric acid (TBA) dan butylated hydroxytoluene (BHT). Sebagai standar adalah larutan standar tetraetoksipropana (TEP).

\section{Pemilihan responden, sosialisasi dan intervensi}

Populasi subjek dipilih berjumlah 17 orang mahasiswa IPB yang secara rutin berolahraga minimal 30 menit perhari tiga kali perminggu atau setara dengan itu. Responden secara keseluruhan hanya terdiri dari pria usia antara 20-27 tahun. Semua responden bertempat tinggal di sekitar kampus IPB Dramaga, Bogor. Responden dipilih berdasarkan hasil pemeriksaan kesehatan oleh dokter di Klinik dr Katili, Dramaga, Bogor. Selanjutnya dilakukan sosialisasi. Saat sosialisasi diberikan penjelasan tentang minuman beroksigen, manfaat, cara konsumsi yang benar, tahapan penelitian dan penandatanganan informed consent (surat perjanjian) bagi responden yang bersedia mengikuti penelitian selama 21 hari. Penelitian dengan menggunakan subjek mahasiswa ini telah mendapatkan persetujuan etik dari Komisi Etik Penelitian Kesehatan, Balai Penelitian dan Pengembangan Kesehatan, Kementerian Kesehatan RI dengan nomor ethical approvalKE.01.10/ $\mathrm{EC} / 650 / 2012$.

\section{Pengujian manfaat minuman beroksigen dalam intervensi jangka pendek}

Sebelum responden (12 orang) melakukan treadmill, responden mengonsumsi AMDK, air beroksigen 50, 80 dan 130 
ppm, masing-masing diminum pada hari yang berbeda. Responden berlari sampai kemampuan maksimum menggunakan treadmill (Woodway) dan cardiorespiratory fitness test "Fitmate" (Cosmed) dengan protokol lari $10 \mathrm{~km} / \mathrm{jam}$. Alat tersebut dihubungkan dengan monitor pemantau EKG. Setelah mengukur kadar asam laktat di awal, dilanjutkan dengan meminum minuman beroksigen (sesuai konsentrasi perlakuan) dilanjutkan dengan treadmill, pengukuran kadar asam laktat setelah treadmill dan 5 menit setelah konsumsi minuman beroksigen (setelah treadmill) menggunakan alat Accutrend Lactat (Roche) dengan mengambil darah dari jari tangan responden. EE diukur selama responden berada di atas treadmill secara otomatis pada alat.

\section{Pengujian manfaat minuman beroksigen dalam intervensi jangka panjang}

Pengambilan darah responden (17 orang) dilakukan sebelum intervensi dan sesudah intervensi air beroksigen selama 21 hari. Konsumsi dilakukan dua kali sehari (pagi dan sore hari) sebanyak $385 \mathrm{~mL}$. Sebelum dan setelah intervensi dilakukan analisa darah responden, juga dilakukan wawancara dengan kuesioner. Kehidupan responden dilakukan seperti biasa dengan diiringi monitoring terhadap kebiasaan olah raga dan istirahat, jenis dan jumlah makan, minum, serta perbaikan kesehatan dan komentar subyektif responden.

Pengambilan darah dilakukan oleh petugas medis dengan mengikuti prosedur standar klinik. Darah yang diambil dari pembuluh vena porta sebanyak $15 \mathrm{~mL}$. Pengambilan darah dilakukan setelah responden menandatangani surat persetujuan (informed consent). Selanjutnya dilakukan isolasi limfosit untuk mendapatkan plasma dan limfosit, kemudian disimpan dalam freezer $-20^{\circ} \mathrm{C}$ untuk selanjutnya dianalisis untuk profil biokimia darah. Parameter biokimia yang diuji yaitu: kadar Malonaldehida (MDA) plasma, analisis kadar CD56, CD4, CD8, IL-6 (pada limfosit).

\section{Analisa kadar malonaldehida dengan metode TBA (modi- fikasi Erniati et al. 2012)}

Sebanyak $100 \mu \mathrm{L}$ plasma darah atau standar tetraetoksipropane (TEP) ditambahkan dengan $75 \mu \mathrm{L}$ larutan TCA $20 \%$ (dalam $\mathrm{HCl} 0.6 \mathrm{~mol} / \mathrm{L} \mathrm{HCl}$ ). Setelah itu didinginkan dalam es selama 20 menit. Campuran tersebut disentrifus pada kecepatan $5.000 \mathrm{rpm}$ selama 20 menit. Kemudian $100 \mu \mathrm{L}$ larutan hasil sentrifus ditambah dengan $20 \mu \mathrm{L}$ pereaksi TBA dan dididihkan selama 30 menit. Setelah didinginkan campuran tersebut dimasukkan dalam microplate 96-well dan absorbansi dibaca menggunakan microplate reader (Labsystem Multiscan EX) pada panjang gelombang $540 \mathrm{~nm}$. Kurva standar dibuat dengan memplotkan nilai absorbansi larutan standar TEP terhadap konsentrasi. Konsentrasi MDA dapat dihitung dengan menggunakan persamaan regresi yang diperoleh dari kurva standar sesuai dengan absorbansi sampel. Kurva standar yang diperoleh memiliki linearitas dengan koefisisen determinas $\left(r^{2}\right)=0.994$.

\section{Isolasi limfosit (modifikasi Wahyuni, 2006)}

Campuran darah dan EDTA disentrifus pada $1.500 \mathrm{rpm}$ selama 10 menit. Plasma dipindahkan ke dalam microtube untuk disimpan pada suhu sekitar $-20^{\circ} \mathrm{C}$ hingga dilakukan analisis. Buffycoat dilewatkan secara perlahan-lahan di atas fycoll-hypaque melalui dinding tabung kemudian disentrifus pada $2.500 \mathrm{rpm}$ selama 30 menit. Selanjutnya dilakukan pencucian limfosit yang bertujuan untuk menghilangkan monosit, plasma dan ficoll-hypaque yang mengkontaminasi. Pencucian dilakukan dengan cara menambahkan PBS kemudian disentrifugasi pada kecepatan $1.500 \mathrm{rpm}$ selama 10 menit. Setelah itu, larutan dibuang dan pelet limfosit yang terdapat pada bagian bawah tabung sentrifus ditambah PBS lagi. Perhitungan menggunakan pewarna trifan blue, dilakukan dengan alat hemasitometer. Jumlah sel disetarakan hingga didapatkan populasi sel limfosit $10^{6} \mathrm{sel} / \mathrm{mL}$. Suspensi disimpan dalam freezer bersuhu $-20^{\circ} \mathrm{C}$ sampai siap dilakukan analisis selanjutnya.

\section{Perhitungan kadar CD4, CD8, CD56 dan IL-6 dengan metode ELISA (modifikasi Anggraeni, 2012)}

Suspensi limfosit/plasma $100 \mu \mathrm{L}$ dimasukkan dalam microplate 96 well, kemudian diinkubasi pada suhu $4^{\circ} \mathrm{C}$ selama semalam. Cairan dalam microplate dibuang dan dicuci dengan $300 \mu \mathrm{L}$ PBST (larutan PBS dengan 0.05\% Tween 20). Selanjutnya ditambahkan $100 \mu \mathrm{L}$ skim milk $3 \%$ pada masing-masing welldan diinkubasi pada suhu $37^{\circ} \mathrm{C}$ selama 2 jam. Cairan dalam microplate dibuang dan dicuci dengan PBST. Kemudian ditambahkan antibodi primer (monoclonal anti CD4/CD8/ CD56/IL-6) sebanyak $100 \mu \mathrm{L}$ (sesuai dengan konsentrasi yang direkomendasikan) dan diinkubasi pada suhu $37^{\circ} \mathrm{C}$ selama 1 jam. Cairan dalam microplate dibuang dan dicuci dengan PBST. Antibodi sekunder (antibodi HRP IgG Anti-mouse untuk antibodi primer CD8, CD56, IL-6 dan antibodi HRP IgG anti-rabbit untuk antibodi primer CD4) ditambahkan sebanyak $100 \mu \mathrm{L}$ dan diinkubasi pada suhu $37^{\circ} \mathrm{C}$ selama 1 jam. Cairan dalam microplate dibuang dan dicuci dengan PBST. Lalu substrat TMB ditambahkan sebanyak $50 \mu \mathrm{L}$ dan diinkubasi pada suhu ruang selama 15 menit dan ditambahkan stop solution. Penghitungan waktu inkubasi dimulai sejak penambahan substrat pada well terakhir. Selanjutnya microplate dibaca dengan microplate reader (Labsystem Multiscan EX) pada panjang gelombang 450 $\mathrm{nm}$.

\section{HASIL DAN PEMBAHASAN}

\section{Kadar asam laktat}

Kadar asam asam laktat menjadi salah satu variabel yang sering diukur dan digunakan untuk mengetahui kinerja atlet. Gambar 1 menunjukkan peningkatan kadar asam laktat sebelum hingga setelah treadmill. Peningkatan kadar asam laktat dengan mengonsumsi minuman beroksigen tidak memberikan efek penghambatan produksi asam laktat jika dikonsumsi sebelum treadmill. Hal ini didukung penelitian Willmert et al. (2002), konsumsi minuman beroksigen dengan konsentrasi oksigen yang lebih rendah $(13.5 \mathrm{~mL} / \mathrm{L})$ sebelum treadmill juga tidak memberikan efek nyata terhadap akumulasi asam laktat. Berbeda jika minuman beroksigen yang dikonsumsi pada saat setelah treadmill (Gambar 1), penurunan kadar asam laktat paling cepat pada kelompok responden minuman beroksigen. 
Hal ini menunjukkan pengaruh konsumsi minuman beroksigen khususnya $130 \mathrm{ppm}$ lebih tinggi pada keadaan kurang oksigen/hypoxia (setelah treadmill) sehingga lebih berfungsi pada pemulihan asam laktat (kelelahan). Rataan dan standar deviasi kadar asam laktat masing-masing perlakuan pada perubahan sebelum treadmill ke setelah treadmill dan setelah treadmill ke 5 menit setelah mengonsumsi minuman beroksigen setelah treadmill ditunjukkan pada Tabel 1. Berdasarkan analisis one way ANOVA, perbedaan antara konsumsi AMDK dan minuman beroksigen menunjukkan hasil yang tidak berbeda signifikan $(p>0.05)$.

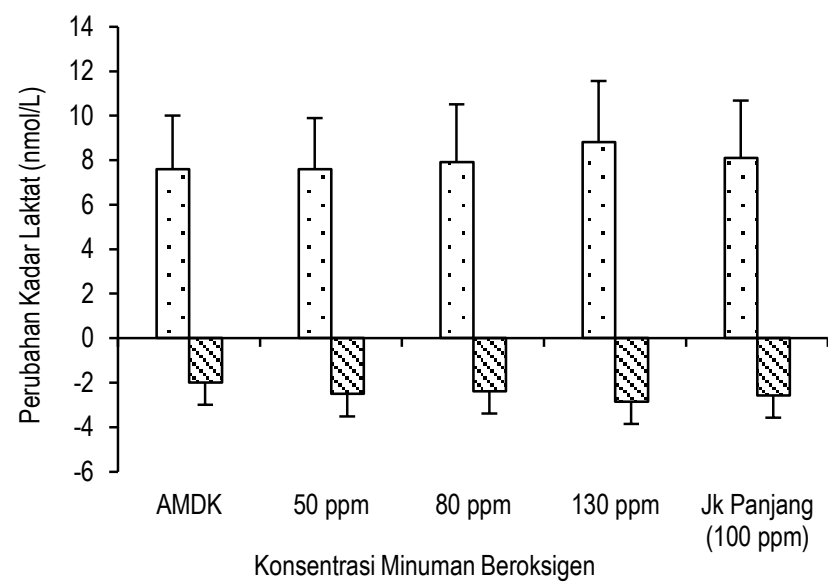

Gambar 1. Peningkatan kadar asam laktat sebelum-setelah treadmill $(\square)$ dan penurunan kadar asam laktat setelah treadmill-5 menit diikuti konsumsi minuman beroksigen $(\mathbb{\nabla})$

Tabel 1. Nilai rata-rata perubahan kadar asam laktat responden $(n=12)$

\begin{tabular}{|c|c|c|c|c|c|c|}
\hline $\begin{array}{l}\text { Pengukuran } \\
\text { Delta } \\
\text { Asam Laktat }\end{array}$ & $\begin{array}{c}\text { Rerata } \\
\pm \text { SD } \\
\text { (AMDK) } \\
\text { (mmol/L) }\end{array}$ & $\begin{array}{c}\text { Rerata } \\
\pm \mathrm{SD} \\
(\mathrm{AO} 50 \\
\mathrm{ppm}) \\
(\mathrm{mmol} / \mathrm{L})\end{array}$ & $\begin{array}{c}\text { Rerata } \\
\pm \mathrm{SD} \\
(\mathrm{AO} 80 \\
\mathrm{ppm}) \\
(\mathrm{mmol} / \mathrm{L})\end{array}$ & $\begin{array}{c}\text { Rerata } \\
\pm \mathrm{SD} \\
(\mathrm{AO} 130 \\
\mathrm{ppm}) \\
(\mathrm{mmol} / \mathrm{L})\end{array}$ & $\begin{array}{c}\text { Rerata } \\
\pm \text { SD } \\
(\mathrm{AO} 100 \\
\mathrm{ppm}) \\
(\mathrm{mmol} / \mathrm{L})\end{array}$ & $\begin{array}{l}\text { One way } \\
\text { ANOVA }\end{array}$ \\
\hline $\begin{array}{l}\text { aSebelum dan } \\
\text { setelah treadmill }\end{array}$ & $\begin{array}{c}7.575 \pm \\
2.407\end{array}$ & $\begin{array}{l}7.642 \pm \\
2.288\end{array}$ & $\begin{array}{c}7.933 \pm \\
2.622\end{array}$ & $\begin{array}{l}8.800 \pm \\
2.754\end{array}$ & $\begin{array}{c}8.125 \pm \\
2.444\end{array}$ & $p=0.764$ \\
\hline $\begin{array}{l}\text { 'Setelah } \\
\text { treadmill dan } 5 \\
\text { menit minum } \mathrm{AO}\end{array}$ & $\begin{array}{c}1.992 \pm \\
1.797\end{array}$ & $\begin{array}{c}2.508 \pm \\
1.326\end{array}$ & $\begin{array}{c}2.392 \pm \\
1.386\end{array}$ & $\begin{array}{c}2.858 \pm \\
1.632\end{array}$ & $\begin{array}{c}2.575 \pm \\
1.509\end{array}$ & $p=0.733$ \\
\hline
\end{tabular}

ab $p$-value $>$ a (0.05), tidak berbeda nyata

\section{Energy expenditure (EE)}

Energy expenditure yang diamati pada penelitian in merupakan jumlah energi yang dikeluarkan atau digunakan oleh tubuh saat melakukan uji performa (treadmill) pada $\mathrm{VO}_{2}$ max. $\mathrm{VO}_{2}$ max adalah kemampuan maksimal seseorang untuk memasukkan oksigen ketika seseorang melakukan aktivitas sampai lelah. Hasil penelitian menunjukkan bahwa secara ratarata energi yang dapat dimanfaatkan oleh responden lebih besar jika mengonsumsi minuman beroksigen (Gambar 2). Asupan oksigen dari minuman beroksigen memungkinkan energi masih dapat dihasilkan. Namun hasil pengujian ANOVA secara statistik $(p=0.05)$ dengan software Minitab 14 menunjukkan pengaruh tidak berbeda nyata antara AMDK dan air minum beroksigen terhadap EE. Kategori performa mengacu Santosa dan Dikdik (2012) adalah sangat buruk: <37.1; buruk: 37.1-41.0; sedang: 41.0-44.2; baik: 44.2-48.2; unggul: 48.2-
54.0; dan superior: >54.0. Jika energi yang digunakan dikelompokkan menurut kategori $\mathrm{VO}_{2} \mathrm{max}$, maka responden yang memiliki $\mathrm{VO}_{2}$ max tinggi $\left(\mathrm{VO}_{2} \max \geq 44.2\right.$ tergolong kategori baik) meng-indikasikan bahwa minuman beroksigen cenderung dapat meningkatkan energi jauh lebih tinggi ketika intervensi dilakukan dalam jangka panjang pada tingkat konsentrasi 100 ppm. Namun, berdasarkan analisis statistik (one way ANOVA), perbandingan ini masih tidak signifikan. Rata-rata dan standar deviasi ditampilkan pada Tabel 2.

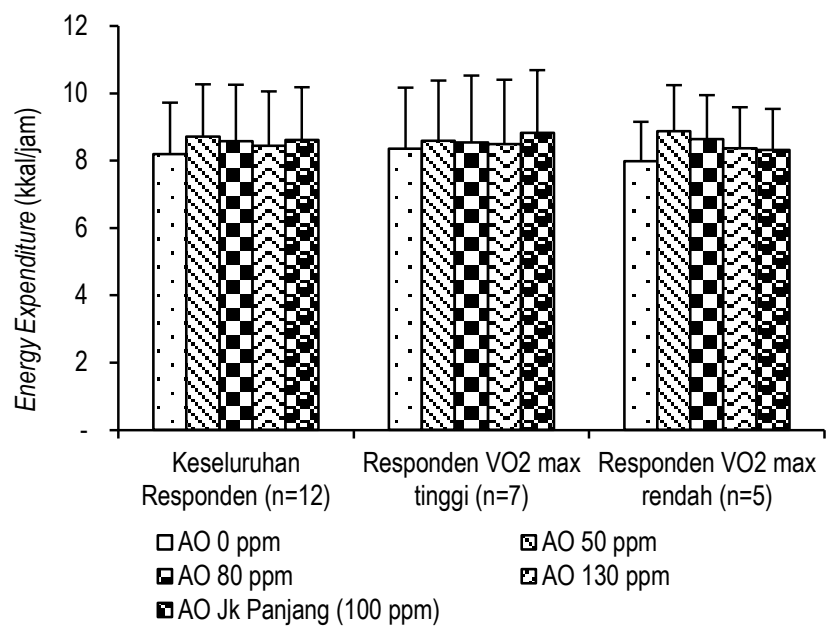

Gambar 2. Rataan \pm SD energy expenditure responden pada saat melakukan treadmill

Tabel 2. Rata-rata \pm SD energy expenditure responden

\begin{tabular}{|c|c|c|c|c|c|c|}
\hline Responden & $\begin{array}{c}\text { Rerata } \\
\pm \text { SD } \\
\text { (AMDK) } \\
\text { (kkal/jam) }\end{array}$ & $\begin{array}{c}\text { Rerata } \\
\pm \text { SD } \\
\text { (AO } 50 \\
\text { ppm) } \\
\text { (kkal/jam) }\end{array}$ & $\begin{array}{c}\text { Rerata } \\
\pm \mathrm{SD} \\
(\mathrm{AO} 80 \\
\mathrm{ppm}) \\
\text { (kkal/jam) }\end{array}$ & $\begin{array}{c}\text { Rerata } \\
\pm \text { SD } \\
\text { (AO 130 } \\
\text { ppm) } \\
\text { (kkal/jam) }\end{array}$ & $\begin{array}{c}\text { Rerata } \\
\pm \mathrm{SD} \\
(\mathrm{AO} 100 \\
\mathrm{ppm}) \\
(\mathrm{kkal} / \mathrm{jam})\end{array}$ & $\begin{array}{l}\text { One way } \\
\text { ANOVA }\end{array}$ \\
\hline $\begin{array}{l}\text { Seluruh } \\
\text { responden } \\
(n=12)\end{array}$ & $\begin{array}{c}819.4 \pm \\
153.0\end{array}$ & $\begin{array}{c}870.8 \pm \\
156.4\end{array}$ & $\begin{array}{c}857.5 \pm \\
167.8\end{array}$ & $\begin{array}{c}843.8 \pm \\
157.2\end{array}$ & $\begin{array}{c}860.6 \pm \\
161.8\end{array}$ & $p=0.945$ \\
\hline $\begin{array}{l}\text { VO2 max } \\
\text { tinggi } \\
(n=7)\end{array}$ & $\begin{array}{c}834.4 \pm \\
182.2\end{array}$ & $\begin{array}{c}859.0 \pm \\
178.5\end{array}$ & $\begin{array}{c}853.0 \pm \\
200.4\end{array}$ & $\begin{array}{c}848.9 \pm \\
187.8\end{array}$ & $\begin{array}{c}881.6 \pm \\
192.0\end{array}$ & $p=0.993$ \\
\hline $\begin{array}{l}\text { VO2 max } \\
\text { rendah } \\
(n=5)\end{array}$ & $\begin{array}{c}798.4 \pm \\
116.8\end{array}$ & $\begin{array}{c}887.2 \pm \\
137.5\end{array}$ & $\begin{array}{c}863.8 \pm \\
130.9\end{array}$ & $\begin{array}{c}836.8 \pm \\
122.3\end{array}$ & $\begin{array}{c}831.2 \pm \\
121.8\end{array}$ & $p=0.836$ \\
\hline
\end{tabular}

$\frac{(\mathrm{n}=5)}{\text { abp-value }>a(0.05), \text { tidak berbeda nyata }}$

Kadar protein CD4, CD8 dan CD56 pada sel limfosit

Limfosit adalah salah satu jenis sel darah putih yang bertanggungjawab pada sistem pertahanan tubuh. Sebanyak 20\% dari semua leukosit dalam sirkulasi darah orang dewasa adalah limfosit, yang terdiri dari sel $\mathrm{T}$ dan sel $\mathrm{B}$ yang merupakan kunci pengontrol sistem imun (Baratawidjaja, 2006). CD4 adalah molekul permukaan sel T helper. Sel Th mengaktifkan makrofag untuk membunuh mikroba dan sel T cytotoxic yang membunuh sel terinfeksi mikroba dan mengeliminasi sumber infeksi. Jumlah CD4 yang tinggi tetapi masih dalam kisaran normal menunjukkan pertahanan spesifik yang baik.

Hasil penelitian menunjukkan peningkatan kadar CD4 berdasarkan rataan nilai optical density. Namun, secara statisik peningkatan kadar protein CD4 akibat konsumsi minuman beroksigen ini tidak signifikan. Rataan dan SD nilai optical density CD4 dapat dilihat pada Tabel 3 dan Gambar 3. 
Tabel 3. Rata-rata \pm SD nilai optical density protein CD4 responden $(n=17)$ sebelum dan setelah intervensi

\begin{tabular}{cccc}
\hline $\begin{array}{c}\text { Parameter } \\
\text { Statistik }\end{array}$ & $\begin{array}{c}\text { Sebelum } \\
\text { Intervensi }\end{array}$ & $\begin{array}{c}\text { Setelah } \\
\text { Intervensi }\end{array}$ & $\begin{array}{c}\text { Uji t- } \\
\text { Berpasangan }\end{array}$ \\
\hline Rata-rata \pm SD & $0.160 \pm 0.082$ & $0.175 \pm 0.066$ & $p=0.301$ \\
\hline$p$-value $0.301>$ a $(0.05)$, tidak teriadi peningkatan signifikan &
\end{tabular}

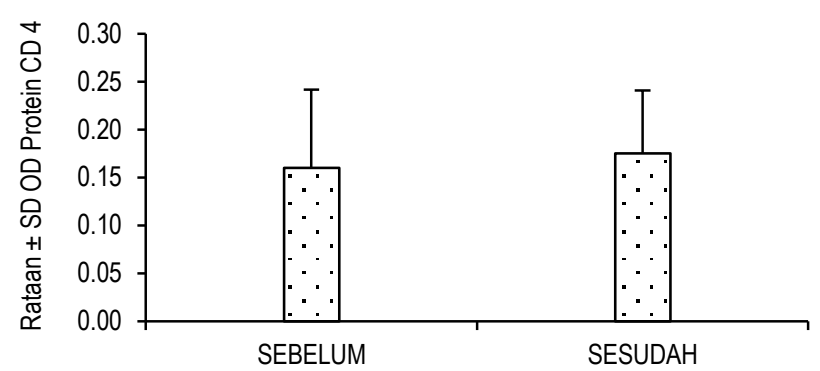

Gambar 3. Rataan nilai optical density CD4

Gambar 4 menunjukkan bahwa peningkatan kadar CD4 terjadi setelah intervensi dengan jumlah responden 12 orang, namun terdapat 5 responden yang mengalami penurunan kadar protein CD4. Jumlah CD4 berkorelasi positif dengan keparahan penyakit, seperti temuan Ray et al. (2006) yang menunjukkan bahwa subyek yang positif HIV mempunyai CD4 yang sangat rendah yaitu $<200 \mathrm{sel} / \mu \mathrm{L}$, sedangkan range normal $\mathrm{CD} 4$ adalah 410-1590 sel/ $\mu \mathrm{L}$.

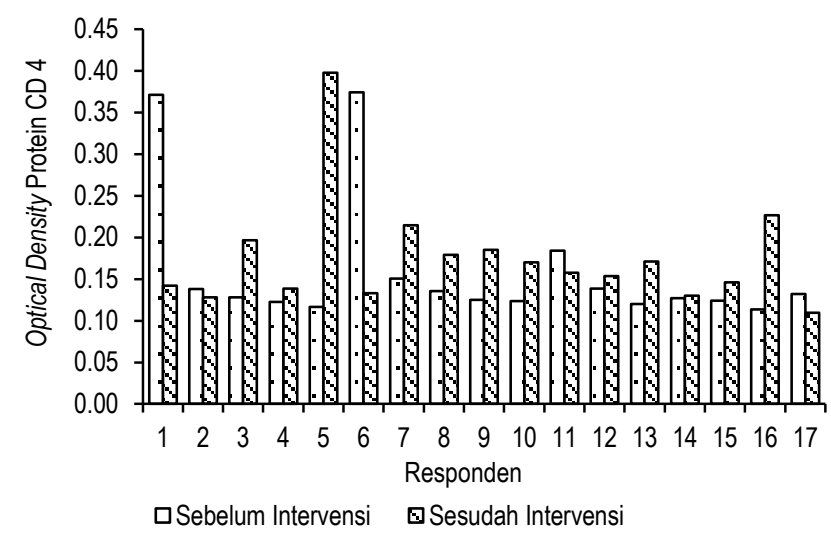

Gambar 4. Nilai optical density CD4 responden sebelum dan sesudah intervensi

CD8 adalah molekul permukaan sel T limfosit, terutama berfungsi sebagai sel T sitotoksik pada imunitas seluler spesifik. CD8 merupakan sel efektor utama yang berperan untuk mengeliminasi virus. Berdasarkan hasil pembacaan sampel dengan ELISA Reader, diperoleh informasi bahwa terjadi peningkatan optical density hanya pada 8 responden saja, sedangkan responden yang mengalami penurunan optical density CD8 terdapat 8 orang responden (Gambar 5). Secara statistik pun tidak menunjukkan perubahan yang signifikan pada CD8 (Tabel 4 dan Gambar 6). Tidak ditemukannya perubahan jumlah CD8 selama suplementasi kemungkinan karena tidak ada sel yang terinfeksi bakteri dan virus sebab sel Tc mempunyai fungsi mengeliminasi sel yang terinfeksi. Proteksi utama respon imun spesifik terhadap bakteri intera seluler adalah dengan melisiskan sel terinfeksi oleh CD8 selain aktivasi makrofag oleh sel CD4 (Ernawati, 2009).

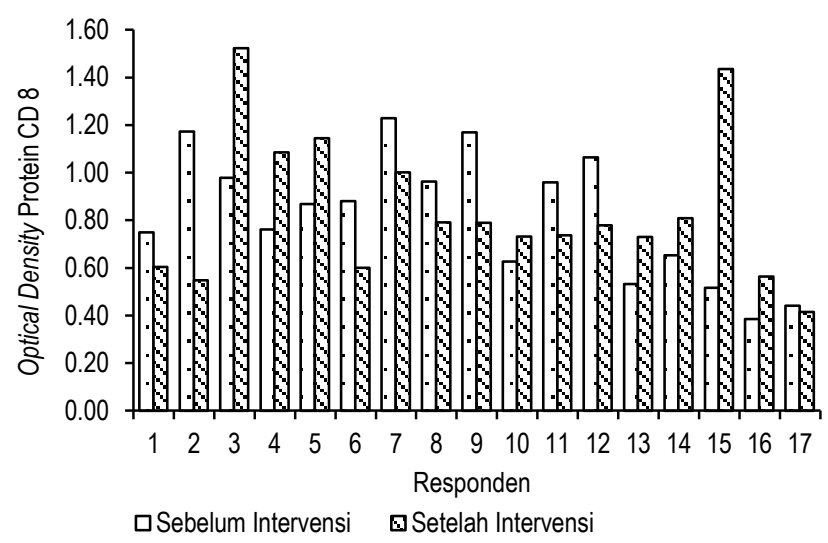

Gambar 5. Nilai optical density CD8 responden sebelum dan sesudah intervensi

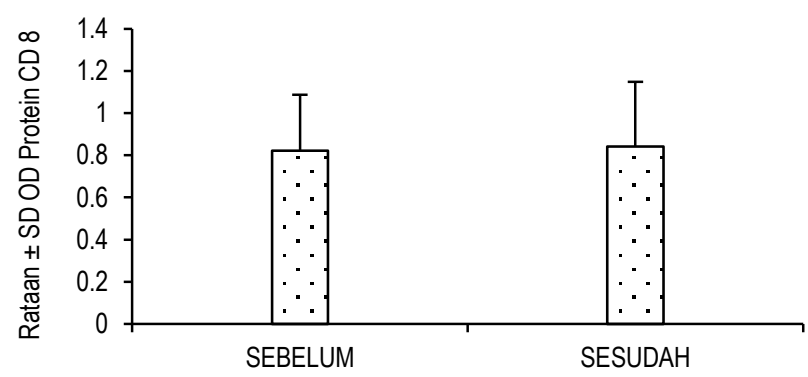

Gambar 6. Rataan nilai optical density CD8

Tabel 4. Rata-rata \pm SD nilai optical density protein CD8 responden $(n=17)$ sebelum dan setelah intervensi

\begin{tabular}{cccc}
\hline $\begin{array}{c}\text { Parameter } \\
\text { Statistik }\end{array}$ & $\begin{array}{c}\text { Sebelum } \\
\text { Intervensi }\end{array}$ & $\begin{array}{c}\text { Setelah } \\
\text { Intervensi }\end{array}$ & $\begin{array}{c}\text { Uji t- } \\
\text { Berpasangan }\end{array}$ \\
\hline Rata-rata \pm SD & $0.821 \pm 0.265$ & $0.841 \pm 0.306$ & $p=0.415$ \\
\hline$p$-value $0.415>a(0.05)$, tidak terjadi peningkatan signifikan &
\end{tabular}

Berbeda dari kadar CD4 dan CD8, kadar CD56 meningkat secara signifikan. Peningkatan kadar protein CD56 ini menunjukkan peningkatan kadar sel NK. Peningkatan optical density CD56 terjadi pada 13 responden. Rataan \pm SD ditampilkan pada Tabel 5 dan Gambar 7.

Tabel 5. Rata-rata \pm SD nilai optical density protein CD56 responden $(n=17)$ sebelum dan setelah intervensi

\begin{tabular}{cccc}
\hline $\begin{array}{c}\text { Parameter } \\
\text { Statistik }\end{array}$ & $\begin{array}{c}\text { Sebelum } \\
\text { Intervensi }\end{array}$ & $\begin{array}{c}\text { Setelah } \\
\text { Intervensi }\end{array}$ & $\begin{array}{c}\text { Uji t- } \\
\text { Berpasangan }\end{array}$ \\
\hline Rata-rata \pm SD & $0.274 \pm 0.052$ & $0.316 \pm 0.101$ & $p=0.039^{*}$ \\
\hline KKarena $p-$ value $0.039<0(0.05)$ maka terjadi peningkatan signifikan
\end{tabular}

"Karena $p$-value $0.039<\alpha(0.05)$, maka terjadi peningkatan signifikan

Hasil pengamatan terhadap limfosit responden sebelum dan sesudah intervensi ditampilkan pada Gambar 8. Sel NK berperan penting di dalam kesehatan manusia. Kadar sel NK rendah merupakan pertanda buruk seperti infeksi virus papilla yang menyebabkan cervical carcinoma, sehingga Anderson (2005) menyatakan bahwa jumlah sel NK yang cukup dapat melindungi seseorang dari infeksi yang mematikan. Penelitian metabolisme dan respirasi seluler yang dilakukan oleh Warburg dalam Mathis (2007) menemukan bahwa sel kanker dapat hidup dan tumbuh jika terjadi keterbatasan oksigen. Jadi, intervensi air beroksigen pada level yang diujikan dapat menstimulasi kerja sel NK, yang diamati dari peningkatannya secara signifikan. 
McMahon (2005) menyimpulkan tentang mekanisme hidup sel kanker bahwa untuk bertahan hidup sel-sel kanker harus berfungsi secara anaerobik sehingga secara implisit diperoleh pengertian bahwa sel yang menghasilkan energi melalui fermentasi (metabolisme anaerob) dapat berubah kanker. Hal ini didukung Huang et al. (2004) yang menyatakan bahwa sel jantung tidak pernah berkembang menjadi sel kanker karena tubuh dirancang sedemikian rupa sehingga jantung tidak dapat mempertahankan metabolisme anaerobik. Karena ketika sel-sel berfungsi secara anaerob, maka sel menghasilkan asam laktat dalam jaringan otot yang dapat menghentikan kerja otot sampai asam laktat dihapus atau dimetabolisme.

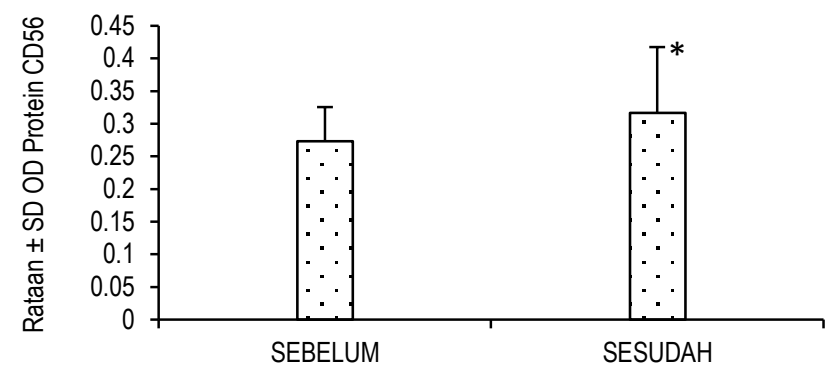

Gambar 7. Rataan nilai optical density CD56

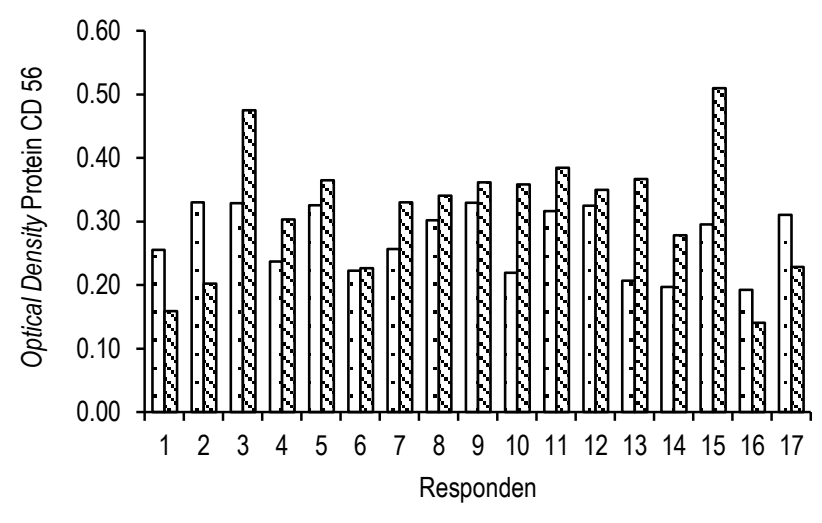

Gambar 8. Nilai optical density CD56 responden sebelum dan sesudah intervensi

\section{Kadar IL-6}

Kadar IL-6 cenderung meningkat dengan adanya aktivitas olah raga. Pedersen et al. (2001) telah mendemonstrasikan secara baik konsentrasi plasma IL- 6 meningkat hingga $>100$ kali selama latihan otot. Temuan dari peningkatan kadar IL-6 setelah latihan konsisten, namun penampakan IL-6 dalam sirkulasi bergantung pada beberapa faktor, termasuk intensitas, durasi, dan bentuk latihan. Minuman beroksigen diharapkan dapat meningkatkan durasi kemampuan melakukan olah raga. Namun, kadar IL-6 juga merupakan salah satu indikator terjadinya inflamasi layaknya TNF-a (Pedersen et al. 2001). Oleh karena itu, peningkatan IL-6 dalam jumlah tinggi juga tidak diharapkan.

Kadar IL-6 berdasarkan rataan nilai optical density menunjukkan penurunan pada penelitian terhadap responden gemar berolahraga. Gambar 9 menunjukkan bahwa tidak terjadi peningkatan kadar IL-6 pada 16 responden tetapi terjadi peningkatan pada seorang responden. Namun, secara statistik perubahan kadar IL-6 ini tidak signifikan. Nilai rata-rata \pm SD optical density kadar IL-6 dapat dilihat pada Tabel 6 dan Gambar 10.

\section{Responden}

$\begin{array}{lllllllllllllllll}1 & 2 & 3 & 4 & 5 & 6 & 7 & 8 & 9 & 10 & 11 & 12 & 13 & 14 & 15 & 16 & 17\end{array}$

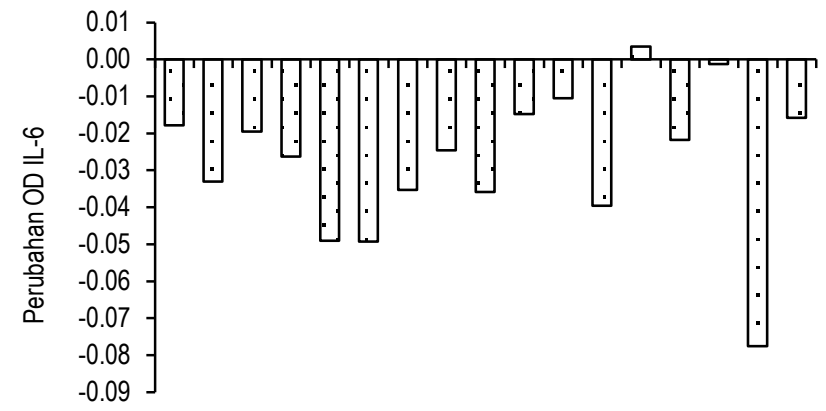

Gambar 9. Perubahan nilai optical density IL-6 responden sebelum dan sesudah intervensi

Tabel 6. Rata-rata \pm SD nilai optical density interleukin-6 responden $(n=17)$ sebelum dan setelah intervensi

\begin{tabular}{cccc}
\hline $\begin{array}{c}\text { Parameter } \\
\text { Statistik }\end{array}$ & Sebelum & Setelah & Uji t- \\
Intervensi & Intervensi & Berpasangan \\
\hline Rata-rata \pm SD & $0.20224 \pm$ & $0.22975 \pm$ & $p=1.00$ \\
& 0.02016 & 0.01729 & \\
\hline
\end{tabular}

Karena $p$-value $1.00>a(0.05)$, terjadi peningkatan signifikan

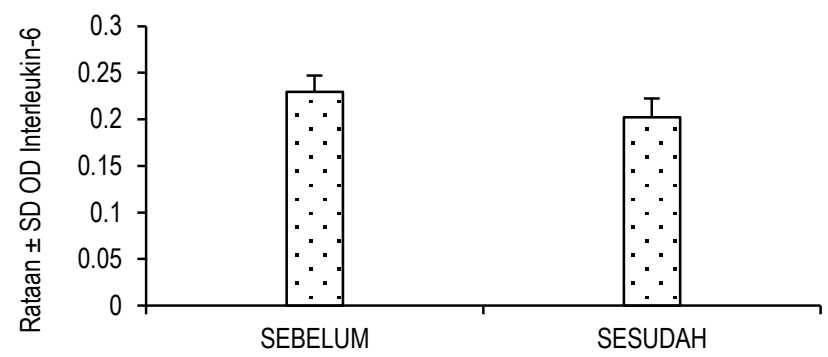

Gambar 10. Rataan optical density interleukin 6 sebelum dan setelah intervensi

Produksi IL-6 lokal berhubungan dengan kontraksi otot dan bukan karena efek sistemik karena IL-6 mRNA meningkat hanya pada otot dari kaki pada saat latihan (bergerak) bukan pada kaki yang beristirahat (Pedersen et al. 2001). Hal ini mungkin yang menyebabkan responden dengan frekuensi olah raga yang cukup tidak menunjukkan peningkatan kadar IL-6 secara signifikan. Secara keseluruhan, hasil penelitian menunjukkan bahwa di antara responden hanya seorang responden mengalami kenaikan kadar IL-6. Berdasarkan pemeriksaan kesehatan, kuesioner dan hasil wawancara, responden tersebut memiliki riwayat hepatitis $A$ dan hasil pemeriksaan dokter menunjukkan adanya gejala bronkitis. Penelitian Mariadi et al. (2008) menunjukkan penyakit yang mendasari terjadinya proses inflamasi menghasilkan IL-6. Jadi, responden tersebut mengalami peningkatan IL-6 bukan karena tindakan intervensi. 


\section{Kadar malonaldehida}

Pengujian terhadap kadar malonaldehida didasarkan pada pentingnya pengujian keamanan konsumsi minuman beroksigen. Latihan fisik dapat meningkatkan konsumsi oksigen sebesar 15 kali lipat dari konsumsi normal dalam aliran darah. Otot yang aktif dapat meningkatkan kebutuhan oksigen 100 kali lipat dari kondisi pasif (Helianti dan Hairrudin, 2011). Proses pembentukan ATP memerlukan oksigen dan konsumsi oksigen pada rantai pernafasan di mitokondria berpengaruh terhadap peningkatan produksi radikal bebas (Cooper et al. 2002). Mengingat manfaat yang diperoleh dari konsumsi air beroksigen adalah untuk meningkatkan performa, diharapkan minuman beroksigen tidak meningkatkan radikal bebas yang ditunjukkan dengan kadar malonaldehida.

Hasil pengukuran terhadap kadar malonaldehida plasma darah menunjukkan penurunan sesudah intervensi minuman beroksigen dari $0.864 \pm 0.182 \mathrm{nmol} / \mathrm{mL}$ menjadi $0.772 \pm 0.185$ $\mathrm{nmol} / \mathrm{mL}$. Perubahan kadar MDA ini tidak signifikan berdasarkan uji t-perbandingan. Hal ini sejalan dengan temuan Handajani et al. (2009) yang menunjukkan penurunan kadar MDA pada subyek diabetes mellitus setelah mengonsumsi air minum beroksigen selama 45 hari.

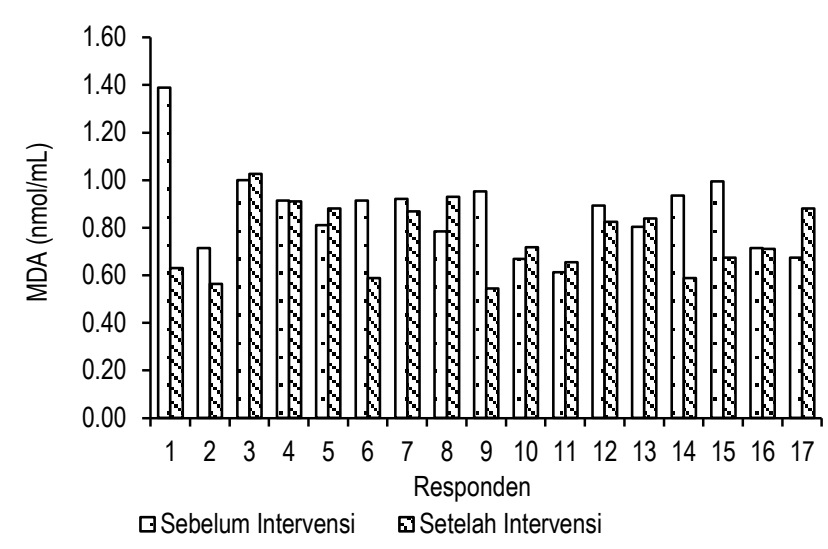

Gambar 11. Kadar malonaldehida responden sebelum dan setelah intervensi

Gambar 11 menunjukkan penurunan kadar malonaldehida terjadi pada 10 responden, sedangkan peningkatan terjadi pada 7 responden. Peningkatan kadar MDA dapat disebabkan oleh banyak faktor. Radikal bebas dapat terbentuk secara endogen maupun eksogen. Secara endogen radikal bebas terbentuk dari reaksi biokimia di dalam tubuh sedangkan secara eksogen radikal bebas dapat terbentuk dari luar tubuh seperti terpapar polusi, asap rokok, makanan, obat-obatan, ataupun iradiasi yang kemudian bereaksi di dalam tubuh. Berdasarkan analisis food recall dan wawancara terlihat bahwa 6 dari 7 responden tersebut memiliki kebiasaan mengonsumsi makanan gorengan dan berminyak berlebihan sedangkan 1 dari 7 responden memperlihatkan konsumsi gorengan yang rendah. Terjadinya peningkatan dimungkinkan karena berdasarkan hasil pemeriksaan kesehatan, responden ini terdeteksi gejala bronkitis. Berbagai penyakit termasuk bronkitis disebabkan oleh oksidan yang berasal dari ROS seperti radikal bebas yang memproduksi malonaldehida selama produksi peroksida lipid (Mahanom et al. 2011).

\section{KESIMPULAN}

Konsumsi minuman beroksigen tidak mempengaruhi parameter performa saat berolahraga seperti EE dan kadar asam laktat, namun nilai rataan penurunan kadar asam laktat lebih tinggi dibandingkan dengan data kadar asam laktat pada responden yang mengonsumsi AMDK dan nilai rataan EE lebih tinggi pada kelompok responden yang mengonsumsi minuman beroksigen. Penurunan kadar asam laktat dan EE yang lebih tinggi ini cukup mendukung performa dan pemulihan setelah berolah raga.

Konsumsi minuman beroksigen juga tidak mempengaruhi kadar CD4 dan CD8 $(p>0.05)$ sebagai parameter sistem imun dalam meningkatkan antibodi, membunuh sel yang termutasi dan terinfeksi virus. Akan tetapi, kadar CD56 meningkat signifikan ( $p>0.05)$. Protein CD56 sebagai protein penanda sel NK yang berfungsi membunuh sel tumor dan sel terinfeksi virus secara langsung. Selain itu, minuman beroksigen tidak memberikan dampak negatif terhadap parameter malonaldehida sebagai parameter stress oksidatif, dan tidak meningkatkan kadar IL-6 yang menjadi indikator inflamasi (peradangan).

\section{DAFTAR PUSTAKA}

Anderson SK. 2005. Biology of natural killer cells: what is the relationship between natural killer cells and cancer? will an increased number and/or function of natural killer cells result in lower cancer incidence? J Nutr 135: 2910 S.

Anggraeni M. 2012. Konsumsi Minyak Sawit Merah Meningkatkan Jumlah Sel Natural Killer dan Menurunkan Kadar Enzim Siklooksigenase 2 pada Ibu Rumah Tangga di Kecamatan Dramaga Bogor [Tesis]. Bogor: Fakultas Teknologi Pertanian, Institut Pertanian Bogor.

Baratawidjaja. 2006. Immunologi Dasar. Jakarta. Fakultas Kedokteran, Universitas Indonesia, Jakarta.

Campbell NA, Mitchell LG, Reece JB. 2000. Biologi Concept and Connection, $3^{\text {rd }}$ Edition. Addison Wesley Longman, Inc., San Fransisco, California.

Cooper CE, Vollaard NB, Choueiri T, Wilson MT. 2002. Exercise, free radicals and oxidative stress. Biochem Soc T 30: 280-285.

Ernawati F. 2009. Pengaruh Suplementasi Multivitamin-Mineral terhadap Imunitas Humoral, Selular dan Status Zat Gizi Antioksidan [Tesis]. Bogor: Fakultas Teknologi Pertanian, Institut Pertanian Bogor.

Erniati, Fransiska RZ, Bambang PP. 2012. Efek konsumsi minuman bubuk kakao (Theobroma cacao $L$.) bebas lemak terhadap sifat antioksidatif limfosit subyek perempuan. J Teknol dan Industri Pangan 23: 81-85.

Handajani YS, Tenggara R, Suyatna FD, Surjadi C, Widjaja NT. 2009. The effect of oxygenated water in diabetes mellitus. Med J Indones 18: 102-107.

Helianti D, Hairrudin. 2011. Efek propolis dalam mencegah infertilitas akibat radikal bebas pada tikus putih (Rattus novergicus) yang diberi stresor. Jurnal Bahan Alam Indonesia 7: 239-243. 
Heryani LGSS, Susari NNW, Kardena IM, Laksmi DNDI. 2011. Paparan formalin menghambat proses spermatogenesis pada mencit. J Veteriner 12: 214-220.

Huang Y, Hickey RP, Yeh JL, Liu D, Dadak A, Young LH, Johnson RS, Giordano FJ. 2004. Cardiac myocyte-specific HIF-1alpha deletion altersvascularization, energy availability, calcium flux, and contractility in thenormoxic heart. FASEB J 18: 1138-1140.

Mariadi IK, Wibawa IDN. 2008. Hubungan antara interleukin- 6 dan C-Reactive Protein pada sirosis hati dengan perdarahan saluran makanan bagian atas. J Peny Dalam 9: 194-202.

Mahanom, Azizah HA, Suhaila M, Nazamid S, Maznah I, Hair MB. 2011. Effect of Centella asiatica extract and powder on hydrogenperoxide-treated Sprague-Dawley rats. J Trop Agric Fd Sc 39: 1-10.

Mathis TH. 2007. Benefit of long-term ingestion of oxygen enriched water. http:// http://www.oxygenorchard.com/wpcontent/uploads/2011/04/Benefits-of-Long-TermIngestion.pdf [10 Juli 2012].

McMahon MCR. 2005. Cellular Extraction Therapy (CET): a possible treatment for cancer?. Gen Sci J: 1-5.

Nestle N, Wunderlich A, Nussle-Kugele K. 2004. In vivo observation of oxygen-supersaturated water in human mouth and stomach. Magn Reson Imaging 22: 551-556.

Orange JS, Ballas ZK. 2006. Natural killer cells in human health and disease. Cl Immunol 118: 1-10.DOI: 10.1016/j.clim. 2005.10.011.

Pedersen BK, Steensberg A, Schjerling P. 2001. Musclederived interleukin-6: possible biological effects. J Physiol 536: 329-337. DOI: 10.1111/j.1469-7793.2001.0329c.xd.
Piantadosi CA. 2006. Oxygenated water and athletic performance. Brit J Sport Med 40: 740-741. DOI: 10.1136/ bjsm. 2006.028936.

Ray K, Gupta SM, Bala M, Muralidhar S, Kumar J. 2006. CD4/CD8 Lymphocytecounts in healthy, HIV-positive individuals \& AIDS patients. T Indian J Med Res 124: 319330.

Santosa HYS, Dikdik ZS. 2012. Fisiologi Olahraga: Fungsi Tubuh Manusia pada Olahraga untuk Kesehatan dan Prestasi. Remaja Rosdakarya, Bandung.

Wahyuni S. 2006. Aktivitas Kitooligomer Hasil Reaksi Enzimatik terhadap Proliferasi Sel Limfosit dan Sel Kanker [Disertasi]. Bogor: Fakultas Teknologi Pertanian, Institut Pertanian Bogor.

Ward JPT, Clarke RW, Linden RWA. 2007. At a Glance Fisiologi. Indah Retno Wardhani (Penerjemah). Erlangga, Jakarta.

Whitham M, Chan MS, Martin P, Matthews VB, Prelovsek O, Lunke S, El-Osta A, Broenneke H, Alber J, Brüning JC, Wunderlich FT, Lancaster GI, Febbraio MA. 2012. Contraction-induced IL-6 gene transcription in skeletal muscle is regulated by C-jun terminalkinase/Activator protein-1. 287: 10771-10779 J Biol Chem DOl: 10.1074/jbc. M111.310581.

Willmert N, Porcari JP, Foster C, Doberstein S, Brice G. 2002. The effects of oxygenated water on exercise physiology during Incremental exercise and recovery. I Exerc Physiolonline 5: 16-21. 